\title{
Zinc oxide surface functionalization and related effects on corrosion resistance of titanium implants
}

\author{
Luciana D. Trino $^{\mathrm{a}, *}$, Leonardo F.G. Dias ${ }^{\mathrm{a}}$, Luiz G.S. Albano ${ }^{\mathrm{a}}$, Erika S. Bronze-Uhle ${ }^{\mathrm{a}}$, \\ Elidiane C. Rangel ${ }^{\mathrm{b}}$, Carlos F.O. Graeff ${ }^{\mathrm{a}}$, Paulo N. Lisboa-Filho ${ }^{\mathrm{a}}$ \\ a São Paulo State University (Unesp), School of Sciences, Bauru 17033-360, Brazil \\ ${ }^{\mathrm{b}}$ São Paulo State University (Unesp), Institute of Science and Technology, Sorocaba 18087-180, Brazil
}

\section{A R T I C L E I N F O}

\section{Keywords:}

Zinc oxide

Biomaterials

Surface functionalization

Corrosion

Functional materials

\begin{abstract}
A B S T R A C T
Important clinical concerns in orthopedics and dental implantology are associated with a significant release of titanium (Ti) metal ions and debris due to the low corrosion resistance of this material. Chemical modifications on Ti surfaces have been performed in order to minimize effects of corrosion. In this contribution, zinc oxide ( $\mathrm{ZnO})$ thin films were deposited onto Ti surfaces and functionalized with four different organic bifunctional molecules in order to increase the corrosion resistance. SEM and XPS indicated the formation of nanostructured $\mathrm{ZnO}$ thin film with hydroxyl groups available for covalent functionalization. The adhesion mechanism analyzed by XPS suggest that the attachment on ZnO occurs by carboxylic acid, silane, thiol and hydroxyl groups for 4aminophenylpropionic acid (APPA), 3-aminopropyltrimetoxysilane (APTMS), 3-mercaptopropionic acid (MPA), and polyethylene glycol (PEG) molecules. Electrochemical analysis for the functionalized ZnO specimens with APPA showed noble open circuit potentials $(-0.2 \mathrm{~V})$ and significant decrease in the corrosion current density $\left(5.3 \times 10^{-7} \mathrm{~A} / \mathrm{cm}^{2}\right)$ when compared to the values obtained for pristine $\mathrm{Ti}\left(-0.56 \mathrm{~V}\right.$ and $\left.2.3 \times 10^{-6} \mathrm{~A} / \mathrm{cm}^{2}\right)$, indicating a promising material for applications in biomedical fields.
\end{abstract}

\section{Introduction}

Titanium (Ti) and its alloys are extensively used as biomaterials in medicine and dentistry due to their biocompatibility [1,2]. In particular, they have a wide range of applications such as dental implants, joints replacement prostheses, cardiac devices and surgical instruments. However, the release of metal ions and debris brings important clinical concerns [3-5]. In the implantation process, the metallic implant is exposed to the electrolyte environment of human body fluid followed by biological and chemical reactions that can arise at the interface between the implant, tissues and bones [6]. These reactions with the physiological environment can result in electrochemical corrosion of the implanted material surface, leading to prosthesis loosening [7]. Moreover, the released metal ions can modify physiological processes and cause detrimental effects on body health in the long term, such as osteomalacia, peripheral neuropathy, Alzheimer's dementia and instability of the implanted material [8-10].

Chemical modifications on Ti surfaces are a way to minimize the effects of corrosion and metal ions release, as well as induce bioactivity of the implant. Suitable surface modification methods have been used to improve the surface properties required for different clinical applications. The most used surface-modifying method is based on the deposition of a protective metal oxide thin film using techniques such as physical vapor deposition (PVD) [11], micro-arc oxidation [12], electrodeposition, sol-gel [13], and magnetron sputtering [14]. The protective metal oxide thin film is stable and can determine the corrosion behavior and tissue biocompatibility of the implant. Considering different oxides used, zinc oxide ( $\mathrm{ZnO}$ ) offers a number of advantages such as low toxicity, high resistance to corrosion, biocompatibility, piezoelectricity and considerable antibacterial activity [15-17]. Furthermore, zinc ( $\mathrm{Zn})$ is present as an essential trace element in more than 300 proteins and is involved in several cellular processes, being a common ion present in many organisms [18]. ZnO thin films can be produced by different techniques, including physical and chemical methods [19]. Among them, the sol-gel technique allows the production of oxide films in large scale at low-cost and excellent substrate adhesion [20].

In addition, ZnO thin films have their surface terminated by hydroxyl groups that can be functionalized by several molecules such as carboxylic acids, esters, acid chlorides and others bifunctional molecules [21], originating an effective control of the surface properties that can result in a more bioactive surface with enhanced corrosion

\footnotetext{
* Corresponding author.

E-mail address: lucianatrino@fc.unesp.br (L.D. Trino).
} 
resistance. Previous studies have indicated that silane treatment on various substrate surfaces can promote cell adhesion, cell proliferation, and hydroxyapatite nucleation to improve osteoblast's adhesion $[22,23]$. Polyethylene glycol have been used on surface functionalization to obtain anti-infective medical implants because it can reduce the bacterial adhesion [24]. Additionally, amine, thiol and carboxylic acid terminated molecules are relevant in the interaction with proteins from the biological environment, which occurs immediately after implant insertion [25-27]. The adsorbed proteins drive the subsequent interaction of the material with cells [28]. So far, however, no functionalization with various functional end groups on $\mathrm{ZnO}$ thin films and their effects on corrosion behavior have been studied, considering the knowledge of the authors.

In this way, we have investigated $\mathrm{ZnO}$ nanoparticles synthetized by the sol-gel method, deposited on commercial pure titanium (Ti cp4) and functionalized with four different bifunctional organic molecules: 3-(4aminophenyl)propionic acid (APPA), (3-aminopropyl)trimetoxysilane (APTMS), 3-mercaptopropionic acid (MPA) and polyethylene glycol (PEG). The structural and physicochemical results correlated with electrochemical tests showed that $\mathrm{ZnO}$ functionalized samples have improved anti-corrosive properties.

\section{Materials and methods}

\subsection{Synthesis and deposition of $\mathrm{ZnO}$ thin film}

The $\mathrm{ZnO}$ resin precursor was obtained by a modified sol-gel Pechini method [29]. ZnO resin was synthetized dissolving citric acid (72.05 g) in deionized water $(200 \mathrm{~mL})$, and subsequently, nitric acid $(15.00 \mathrm{~mL})$ was added to the mixture with zinc oxide $(10.17 \mathrm{~g})$. The molar ratio between $\mathrm{ZnO}$ and citric acid was 1:3, respectively. The solution was then heated to $100{ }^{\circ} \mathrm{C}$ for $15 \mathrm{~min}$. Finally, ethylene glycol was added to the solution considering the ratio between the citric acid and ethylene glycol mass $60 / 40$, respectively. Following, the temperature was increased to $150{ }^{\circ} \mathrm{C}$ and the solution kept under magnetic stirring until reach $100 \mathrm{~mL}$. Then, the solution was diluted in a ratio of $5 \mathrm{~mL}$ of deionized water to $3 \mathrm{~mL}$ of $\mathrm{ZnO}$ resin.

Commercial pure titanium grade 4 (Ti cp4 (ACNIS)) discs, diameter $12.7 \mathrm{~mm}$ and thickness $3 \mathrm{~mm}$, were polished until the arithmetic mean roughness $(\mathrm{Ra})$ reaches $\approx 143 \mathrm{~nm}$, which is in the range of the values found in commercially available dental implants $(100-1000 \mathrm{~nm})$ [30-32].

Then Ti cp4 was cleaned with isopropanol and deionized water for 15 min each in ultrasonic bath. After, the discs were etched and hydroxylated in Piranha solution (mixture of 7:3 (v/v) $98 \% \mathrm{H}_{2} \mathrm{SO}_{4}$ and $30 \% \mathrm{H}_{2} \mathrm{O}_{2}$ ) for two hours and then rinsed with deionized water. The Piranha solution is a strong oxidizer that can form hydroxyl groups on the Ti surface, making it extremely hydrophilic to bond with $\mathrm{ZnO}$, improving the oxide thin film adhesion.

The $\mathrm{ZnO}$ deposition was performed by three sequential spin coating (2000 rpm, $60 \mathrm{~s}$ ) steps using $60 \mu \mathrm{L}$ of $\mathrm{ZnO}$ solution for each step. For each $\mathrm{ZnO}$ deposition, the samples were heated during $5 \mathrm{~min}$ in a hot plate at $70^{\circ} \mathrm{C}$. With the three $\mathrm{ZnO}$ layers, a thermal treatment with two steps was performed: $350{ }^{\circ} \mathrm{C}$ during $2 \mathrm{~h}$ at $1{ }^{\circ} \mathrm{C} / \mathrm{min}$ followed by $500{ }^{\circ} \mathrm{C}$ during $30 \mathrm{~min}$ at $5^{\circ} \mathrm{C} / \mathrm{min}$.

\section{2. $\mathrm{ZnO}$ functionalization}

The $\mathrm{ZnO}$ surface was functionalized using the immersion method described as follows. After the deposition of the organic molecules all samples were dried in ambient conditions. The adhesion stability of the bifunctional molecules is discussed at the Supporting information (Fig. S1).

\subsubsection{3-(4aminophenyl)propionic acid (APPA)}

APPA solution ( $2 \mathrm{mM}$ ) was prepared in ethanol absolute by stirring the solution during $5 \mathrm{~min}$. After complete dissolution it was heated to $40{ }^{\circ} \mathrm{C}$ and then samples were immersed for $5 \mathrm{~min}$.

\subsubsection{3-aminopropyltrimetoxysilane (APTMS)}

APTMS solution $(10 \mathrm{mM})$ was prepared in ethanol absolute and samples were immersed in the solution for $1 \mathrm{~min}$ at room temperature.

\subsubsection{3-mercaptopropionic acid (MPA)}

An aqueous MPA solution ( $1 \mathrm{mM})$ was prepared adjusting the solution $\mathrm{pH}$ to 3 with $\mathrm{HCl}$. Then, samples were immersed for $10 \mathrm{~min}$ in the solution under room temperature.

\subsubsection{Polyethylene glycol (PEG)}

A mixture in the ratio 1:4 of PEG to distilled water was prepared. The substrates were added to the solution and kept overnight, then rinsed with deionized water.

\subsection{Characterization}

\subsubsection{X-ray diffraction (XRD)}

The crystalline orientation of $\mathrm{ZnO}$ films were measured at room temperature using an X-ray diffractometer (D/MAX-2100/PC, Rigaku). The scanning range was from $20^{\circ}$ to $45^{\circ}$, with steps of $0.02^{\circ}$ and scan speed of $2^{\circ} \mathrm{min}^{-1}$. In order to determine the crystal structure, results were compared with PCPDF 65-3411, 44-1294 and 76-1949 cards for $\mathrm{ZnO}$, $\mathrm{Ti}$ and $\mathrm{TiO}_{2}$, respectively.

\subsubsection{Scanning electron microscopy (SEM)}

The morphological characterization of the thin films was performed by Scanning Electron Microscopy (FEG-SEM JEOL 7500F). For crosssection images, the $\mathrm{ZnO}$ layer was deposited on a silicon substrate coated with Ti. A diamond cutter was used to cut the Si-Ti substrate coated with $\mathrm{ZnO}$ from the backside of the sample. The samples were coated with gold and mounted on an aluminum stub with a doublesided conductive carbon tape for imaging the surface and the crosssection of the samples. The analysis was performed applying a voltage of $2.00 \mathrm{kV}$ and a working distance of $8 \mathrm{~mm}$.

\subsubsection{X-ray photoelectron spectroscopy (XPS)}

XPS analysis was carried out in a Kratos (AXIS-165) using a monochromatic $\mathrm{Al} \mathrm{K \alpha} \mathrm{X}$-ray source. Each sample was analyzed at takeoff angle of $54.7^{\circ}$, defined as the angle of emission relative to the surface. The energy resolution was $0.45 \mathrm{eV}$. Survey scan spectra were recorded with a pass energy of $80 \mathrm{eV}$ and individual high-resolution spectra with a pass energy of $20 \mathrm{eV}$. In order to correct for any charging effect, binding energy of the Ti $2 p$ peak was normalized to $458.8 \mathrm{eV}$. Curve fitting was performed using the CasaXPS software. Peak identification was done to obtain a consistent fit for all the potentials investigated.

\subsubsection{Contact angle and surface energy}

The contact angle and surface energy were evaluated by the sessile drop technique in a goniometer (Ramé-Hart, 100-00) and using deionized water (polar substance), and diiodomethane (non-polar substance) as the probing liquids. At least three droplets were deposited on different positions of the samples and contact angle was measured at each side of the drop. Measurements were performed in triplicates, at room temperature, and under controlled humidity environment. The contact angle and surface energy were evaluated by appropriate software.

\subsubsection{Surface roughness}

Surface roughness characterization was performed by confocal microscopy (Leica DCM3D) employing a $20 \mathrm{x}$ lens. The arithmetic mean roughness ( $\mathrm{Ra}$ ) were determined by calculating the average value from six randomly selected areas for each sample. 


\subsubsection{Corrosion}

Electrochemical tests were conducted with a Metrohm Autolab PGSTAT302 equipped with a FRA32M module using a standard threeelectrode corrosion cell. Samples were used as the working electrode with about $1 \mathrm{~cm}^{2}$ of exposed surface area to corrode. The other two electrodes were a counter electrode made of a platinum wire and an $\mathrm{Ag} / \mathrm{AgCl}$ as reference. A quantity of $40 \mathrm{~mL}$ of PBS was used for each sample as the electrolyte. All tests were performed at the physiological temperature of $37^{\circ} \mathrm{C}$ using a hot plate. Each group sample was analyzed in triplicate.

The electrochemical protocol consisted of five electrochemical steps. The first one was an open circuit potential (OCP) performed during $300 \mathrm{~s}$, to assure that the electrochemical cell was setup correctly in the electrical connections. In the sequence, a second OCP was performed during $3600 \mathrm{~s}$, allowing the sample to stabilize in the specific conditions of the electrochemical cell. The third was an electrochemical impedance spectroscopy (EIS), which measured the surface properties of the sample to obtain the specific features from the interface through an equivalent circuit approach. EIS measurement was performed at the open circuit potential $\left(E_{\text {ocp }}\right)$ obtained during the second OCP, with potential amplitude of $\pm 10 \mathrm{mV}$ and frequency range between $100 \mathrm{kHz}$ and $0.01 \mathrm{~Hz}$. The fourth test was a potentiodynamic polarization (PD) performed by a cyclic polarization between $-0.8 \mathrm{~V}$ and $+1.8 \mathrm{~V}$ to determine the corrosion potential $\left(\mathrm{E}_{\text {corr }}\right)$ and corrosion current density $\left(\mathrm{I}_{\text {corr }}\right)$ using Tafel extrapolation [7]. The final OCP test was performed during $600 \mathrm{~s}$ to measure any change in the open circuit potential.

\section{Results and discussion}

\subsection{Characterization of the $\mathrm{ZnO}$ thin film}

As shown in Fig. 1a, ZnO thin film presents diffraction peaks at $2 \theta$ equal to $31.8^{\circ}(100), 34.5^{\circ}(002)$ and $36.3^{\circ}(101)$. These diffraction peaks correspond to the characteristic structure of the hexagonal wurtzite phase from $\mathrm{ZnO}$ nanoparticles [33]. The diffraction correspondent to the (101) plane is more intense, indicating that the $\mathrm{ZnO}$ crystallites are preferentially oriented. In addition to the $\mathrm{ZnO}$ wurtzite peaks, it is possible to observe rutile $\mathrm{TiO}_{2}$ as well as the metal Ti peaks. The presence of $\mathrm{TiO}_{2}$ is from the native oxide layer on the Ti cp4 surface that crystallized in the rutile polymorphic phase after thermal treatment, while the metallic Ti present in the substrate is detected due to the $\mathrm{ZnO}$ thin film thickness $(\sim 100 \mathrm{~nm})$ as shown in the cross-section of SEM image in Fig. 1b. The nanostructured morphology of the films can be confirmed by the SEM image presented in Fig. 1c where the nanoparticles presents a circular shape with average size of $67.0 \pm 8.5 \mathrm{~nm}$.

\subsection{Surface physicochemistry of functionalized $\mathrm{ZnO}$ thin film}

XPS results presented an increase in C $1 s$ intensity for all functionalized samples when compared to pristine $\mathrm{ZnO}$ thin film. The amount of adventitious carbon is around $23 \%$ and it is discussed at the Supporting information. The presence of $\mathrm{C} 1 \mathrm{~s}$ associated with the specific atomic peaks of each organic molecule is an indicative of an effective functionalization of $\mathrm{ZnO}$ thin films, Fig. 2a. The $\mathrm{O} 1 \mathrm{~s}$ spectrum of $\mathrm{ZnO}$ showed three different contributions as shown in Fig. 2b, the highest energy peak at $532.0 \mathrm{eV}$ is related to the $\mathrm{O}-\mathrm{H}$ bonds. The metal oxide ( $\mathrm{Zn}-\mathrm{O}$ ) bonds appear in $530.5 \mathrm{eV}$ while in $528.9 \mathrm{eV}$ the occurrence of Ti-O bonds, related to the native oxide from the Ti cp4 substrate. The atomic percentage of the $\mathrm{O}-\mathrm{H}$ peak contribution in $\mathrm{ZnO}$ is around $50.5 \%$, showing that the surface is well covered with hydroxyl groups, acting as anchor points for the formation of organic molecules monolayers or multilayers $[34,35]$.

Analyzing the $\mathrm{C} 1 \mathrm{~s}, \mathrm{O} 1 \mathrm{~s}$ and $\mathrm{N} 1 \mathrm{~s}$ high-resolution spectra for the functionalized samples it is possible to evaluate which functional group from each organic molecule is attached to the $\mathrm{ZnO}$ surface. The highresolution spectra from $\mathrm{C} 1 \mathrm{~s}$ are shown in Fig. 3a. APPA presented the (a)
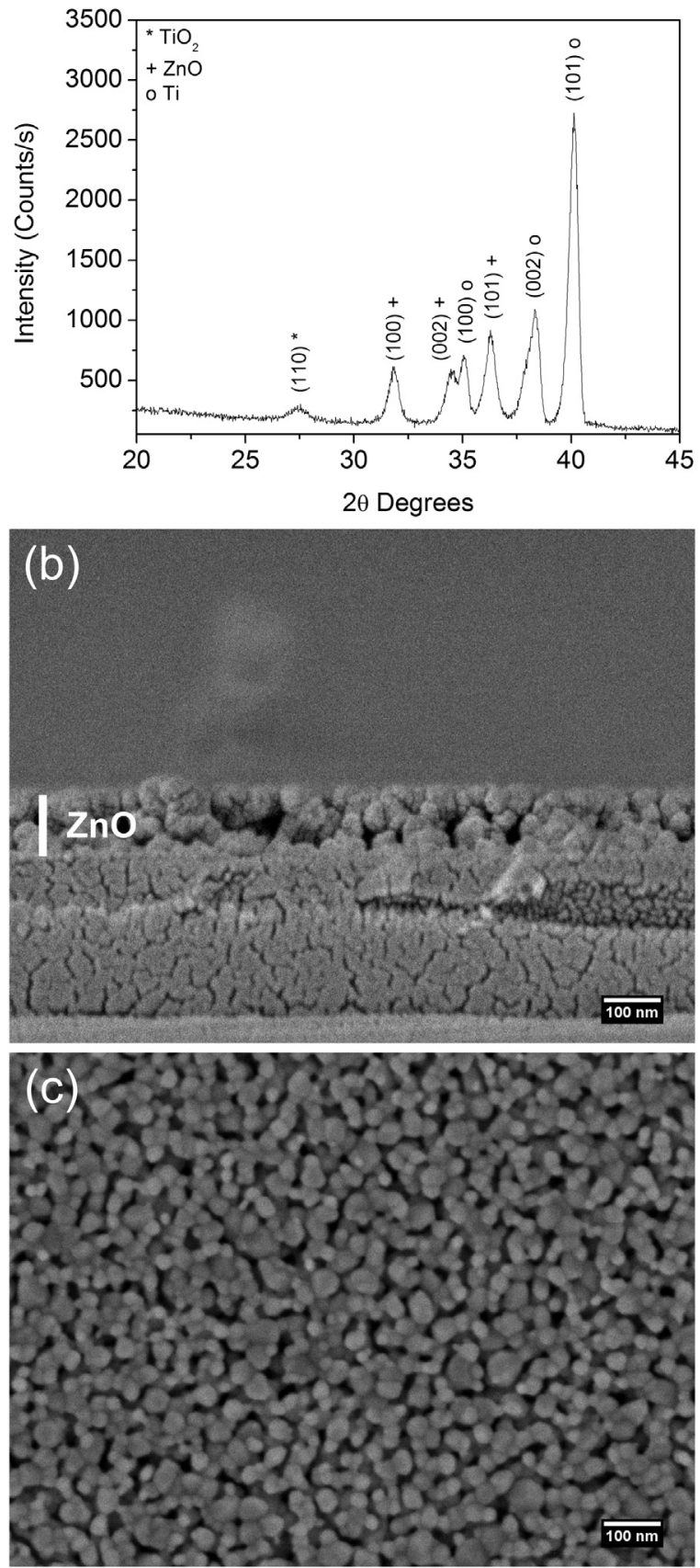

Fig. 1. XRD spectrum (a), SEM images from cross-section (b) and top surface (c) of ZnO thin films. Magnification of SEM images is $100,000 \mathrm{x}$.

interactions C-C (285.0 eV), C-N (286.7 eV) and $\mathrm{COOH}(288.9 \mathrm{eV})$ [36]. For APTMS, it is possible to observe three contributions at 285.2, 286.2 and $289.0 \mathrm{eV}$ related to $\mathrm{C}-\mathrm{C}, \mathrm{C}-\mathrm{N}$ and $\mathrm{C}-\mathrm{Si}-\mathrm{O}$ bonds, respectively. The interaction between MPA and $\mathrm{ZnO}$ might occur through thiol groups, since free carboxyl groups were observed at $288.7 \mathrm{eV}$ in the $\mathrm{C} 1 \mathrm{~s}$ spectrum. In addition, contributions for the C-S $(286.5 \mathrm{eV}), \mathrm{C}-\mathrm{C}$ $(284.9 \mathrm{eV})$ and C-Zn $(282.7 \mathrm{eV})$ bonds were shown [36], C-Zn may appear due to contaminations. PEG has several hydroxyl groups available to crosslink with each other, showing a higher intensity for C 1 s when compared with the others bifunctional molecules, with contributions for C 1 s at 284.5 and $286.0 \mathrm{eV}$, referent to $\mathrm{C}-\mathrm{C}$ and $\mathrm{C}-\mathrm{OH}$ bonds, respectively [37].

In Fig. $3 \mathrm{~b}$ the $\mathrm{O}$ 1s high-resolution spectra for the functionalized 

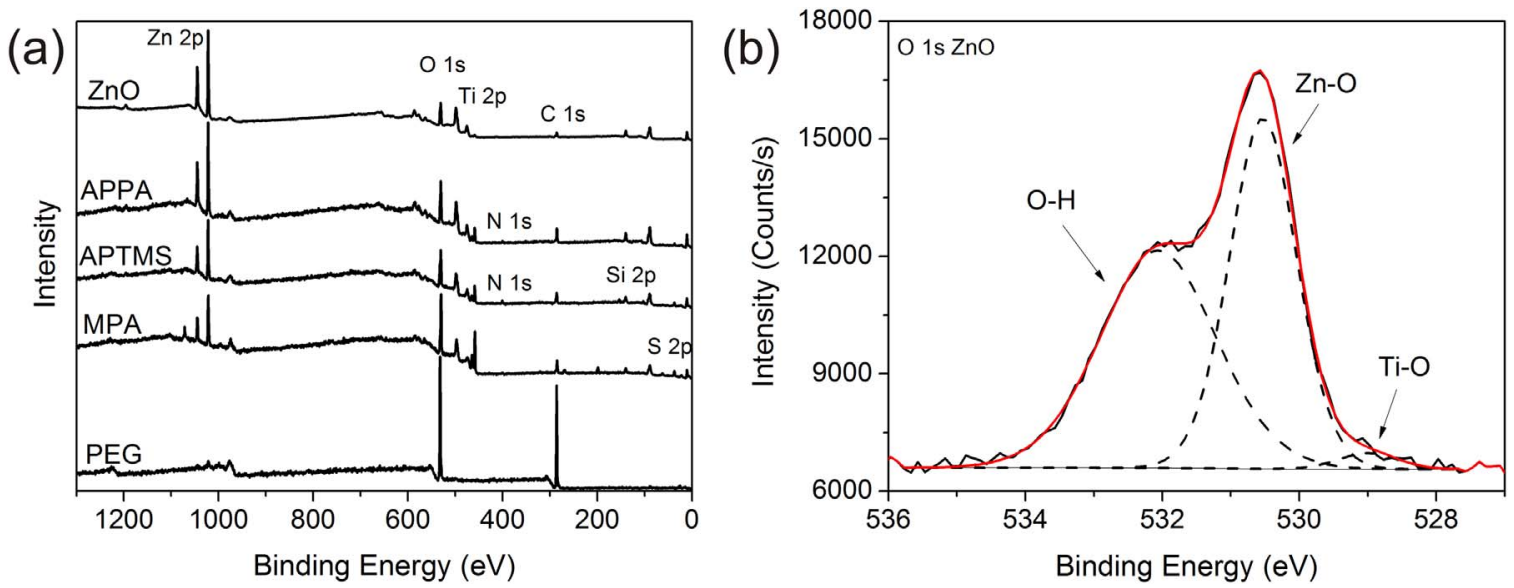

Fig. 2. XPS spectra of ZnO thin film and the functionalized samples with APPA, APTMS, MPA and PEG (a). A high-resolution spectrum from O 1s in ZnO is shown in (b).

samples is shown. The APPA exhibited the presence of Ti-O, Zn-O and $\mathrm{COO}^{-}$bonds in 529.2, 530.4 and $531.9 \mathrm{eV}$, respectively. In APTMS four contributions are found: the first two in 528.5 and $530.2 \mathrm{eV}$ are related to the oxygen bonded to $\mathrm{Ti}$ and $\mathrm{Zn}$, respectively; and the highest energy peak can be attributed to O-Si-O (532.1 eV) [38], indicating the adhesion of APTMS molecules by silane groups. For MPA, the presence of $\mathrm{Ti}-\mathrm{O}, \mathrm{Zn}-\mathrm{O}$ and $\mathrm{COOH}$ or $\mathrm{S}-\mathrm{O}$ bonds in $528.7,530.1$ and $531.6 \mathrm{eV}$ is seen, respectively. For samples functionalized with PEG, the presence of $\mathrm{Zn}-\mathrm{O}(530.6 \mathrm{eV})$ and $-\mathrm{CH}_{2}-\mathrm{CH}(\mathrm{OH}-) \mathrm{n}(532.3 \mathrm{eV})$ bonds are observed [37], suggesting the formation of a polymeric layer. The decrease in $\mathrm{Zn}$ $2 p$ and Ti $2 p$ peaks intensity followed by an increase in $O 1 s$ and $C 1 s$ after PEG deposition corroborates with the fact that PEG may polymerize forming crosslinked structures.

Considering the high-resolution spectra of $\mathrm{N} 1 \mathrm{~s}$ for APPA and
APTMS molecules (Fig. 4), the adsorption of APPA on the $\mathrm{ZnO}$ surface might have a preferential attachment through the carboxylic acid group. In N 1s spectra, the presence of free amine $\left(\mathrm{C}-\mathrm{NH}_{2}\right)$ at $397.2 \mathrm{eV}$, $\mathrm{C}-\mathrm{N}$ at $399.9 \mathrm{eV}$ and $\mathrm{NH}_{3}{ }^{+}$at $403.2 \mathrm{eV}$ was identified. The presence of $\mathrm{NH}_{3}{ }^{+}$is due to the formation of the zwitterionic amine, which associated with the existence of free $\mathrm{NH}_{2}$, favors adsorption through the COOH groups $[39,40]$. The $\mathrm{N} 1 \mathrm{~s}$ spectrum for APTMS shows the presence of free $\mathrm{C}-\mathrm{NH}_{2}$ group $(400.3 \mathrm{eV})$. Combining the $\mathrm{N} 1 \mathrm{~s}$ and $\mathrm{O} 1 \mathrm{~s}$ data is evident that the APTMS molecules effectively adhered to the surface by covalent bond through silane groups [41].

According to the XPS data, a possible attachment model between the $\mathrm{ZnO}$ surface and the organic bifunctional molecules are shown in Fig. 5. The presence of $\mathrm{COO}^{-}$in APPA indicates that this site can interact with the metal $\mathrm{Zn}$ (Fig. 5a). Furthermore, the APPA solution pH is 6.4
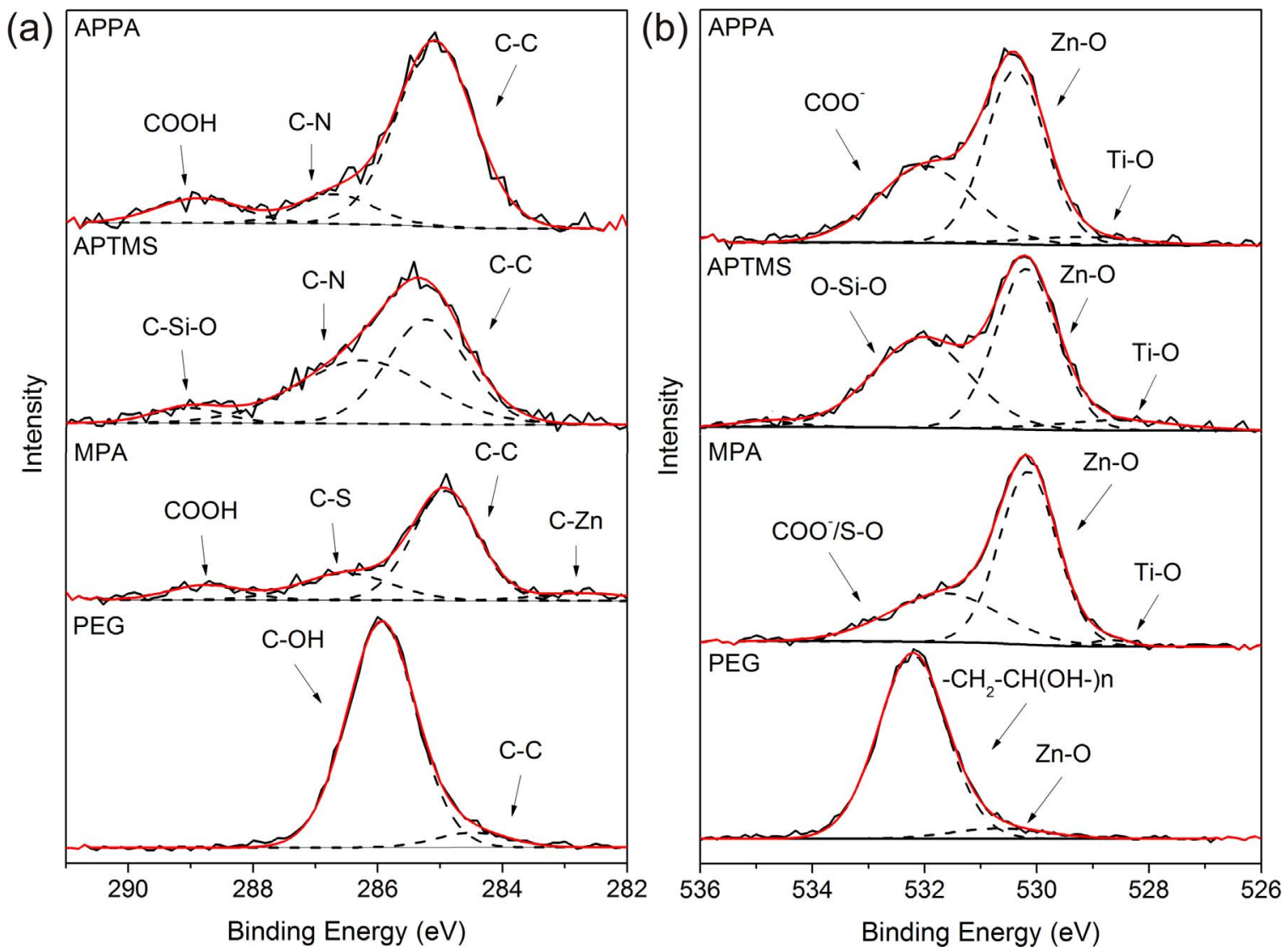

Fig. 3. High-resolution XPS spectra of $\mathrm{C}$ 1s (a) and O 1s (b) for ZnO thin film functionalized with APPA, APTMS, MPA and PEG. 


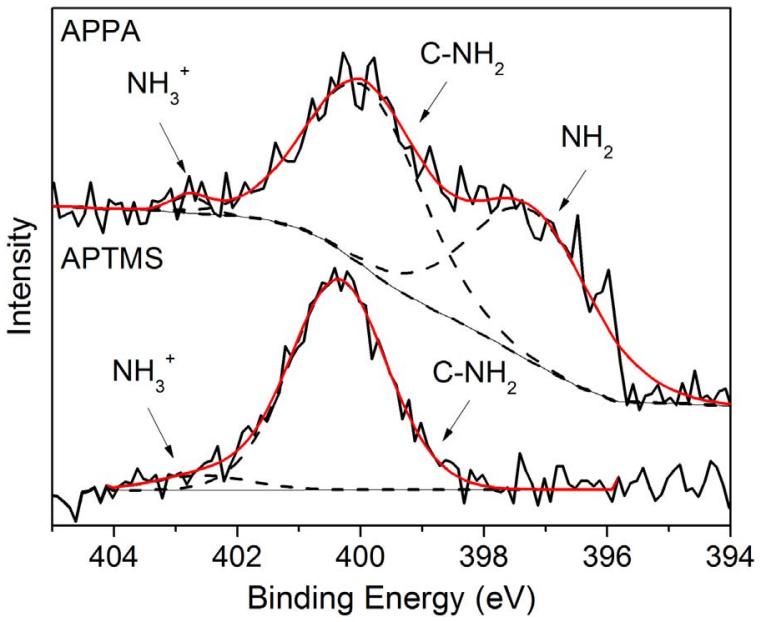

Fig. 4. High-resolution spectra of $\mathrm{N} 1 \mathrm{~s}$ for the $\mathrm{ZnO}$ surfaces functionalized with APPA and APTMS molecules.
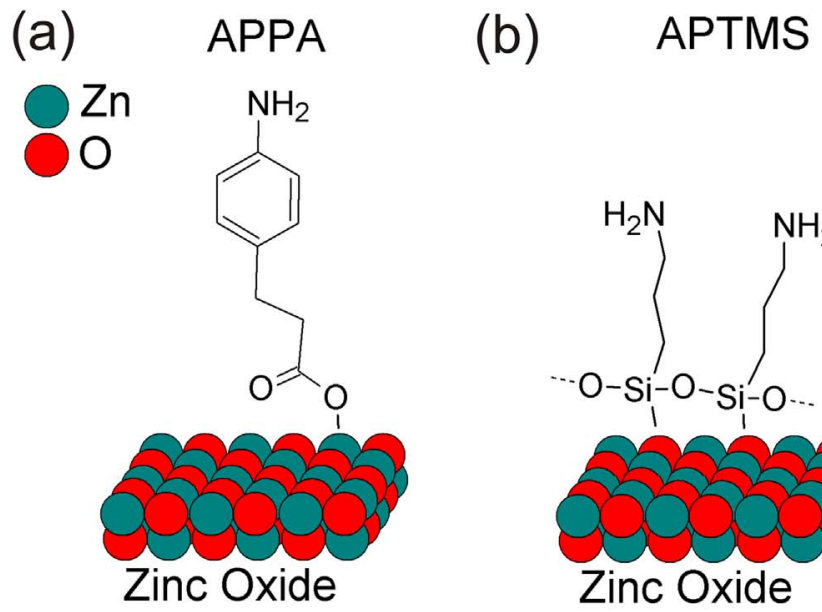

(c)

MPA

(d)
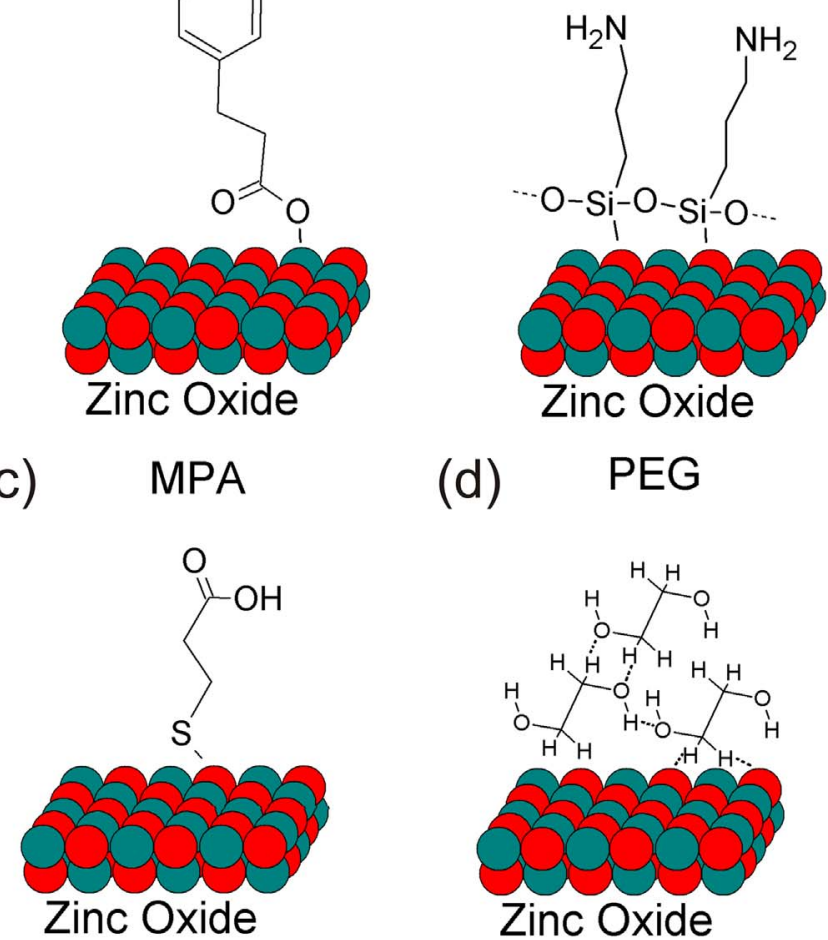

O-Si-O denoted the APTMS adhesion by the silane group (Fig. 5b) $[44,45]$. For MPA, the presence of S-O bonds is an indicative that the thiol groups might have interacted with the hydroxyl groups present on the $\mathrm{ZnO}$ surface (Fig. 5c). After adhesion through hydroxyl groups (Fig. 5d), PEG chains can self-interact due to the presence of several $-\mathrm{OH}$ groups that result in crosslinking bonds.

The contact angle characterization employing water as probe has been often used as a simple method for accessing the physicochemical properties of modified surfaces [46]. Surface energy and contact angle are inversely proportional to each other and by nature, zinc oxide surfaces are hydrophobic [47]. The results for the contact angle measurements of pristine and functionalized $\mathrm{ZnO}$ thin films are summarized in Fig. 6a. The pristine $\mathrm{ZnO}$ thin film as expected is hydrophobic, with a surface water contact angle of $81^{\circ}$ [48]. The APPA grafting produced just a small increase in hydrophobicity, with respect to the as-deposited $\mathrm{ZnO}$, showing a water contact angle of $83^{\circ}$. The surface functionalization with APTMS decreased the wettability of $\mathrm{ZnO}$, showing a water contact angle of $89^{\circ}$. The MPA functionalization preserved the water contact angle of $81^{\circ}$. PEG was the only molecule that tailored the surface with hydrophilic properties, exhibiting a water contact angle of $18^{\circ}$. As the $\mathrm{C}-\mathrm{O} / \mathrm{CH}_{2}$ ratio increases for PEG molecule the contact angle decreases [49], in this way, the existence of oxygen in the backbone $-\left(\mathrm{CH}_{2} \mathrm{CH}_{2} \mathrm{O}-\right) \mathrm{n}$ is responsible for this behavior. Furthermore, in molecules with more than 10 carbon atoms, such as PEG, the chains interact randomly on the surface, contributing to obtain a very smooth, ultrathin, and highly hydrophilic surface [50].

Therefore, the surface wettability can be controlled by the addition of the organic bifunctional molecules and the specific surface characteristics will be defined by the bio-application. The APPA, APTMS, and MPA surfaces showed less wettability that may improve the bactericidal efficacy of the functional materials [51], while the PEG hydrophilic surface may positively influence cell-surface interactions [52].

The organic molecule adhesion induced relevant changes in the physicochemical properties of the surface. The wettability of solid surfaces is a very important property, and is determined by the surface geometric structures as well as the chemical composition of surfaces, which is dictated by the polar component of the surface energy $[53,54]$. The surface energy of ZnO functionalized with APTMS and MPA is lower than pristine sample. However, as shown in Fig. 6b, APPA and PEG increased the surface energy. According to XPS data, this behavior is related to the type of functional groups available on the surface. The surface charges from $-\mathrm{NH}_{2}$ and - $\mathrm{COOH}$ groups present in the APTMS and MPA molecules are lower when compared with the hydroxyl from PEG, and amine groups bonded to the aromatic chain present in APPA. Furthermore, the higher carbon content of APTMS leads to more hydrophobic interactions. On the other hand, the presence of free amine groups and an aromatic chain with delocalized electrons in APPA increased the total charge of the molecule, enhancing consequently the surface energy. In the case of PEG, the high density of hydroxyl groups led to an increase in surface energy, which changed the $\mathrm{ZnO}$ thin film surface from non-polar to polar.

The arithmetic mean surface roughness ( $\mathrm{Ra}$ ) was analyzed for the pristine Ti substrate, $\mathrm{ZnO}$ thin film, and the functionalized oxide thin films (Fig. 7). The Ra values indicates that surface roughness increased from $143( \pm 13) \mathrm{nm}$ to $191( \pm 3) \mathrm{nm}$ with $\mathrm{ZnO}$ thin film deposition on Ti substrate. After APPA and MPA deposition no significant changes in Ra surface roughness was observed and the values correspond to 187 $( \pm 17) \mathrm{nm}$ and $180( \pm 13) \mathrm{nm}$. Nevertheless, it increased to 249 $( \pm 16) \mathrm{nm}$ and $222( \pm 13) \mathrm{nm}$ with APTMS and PEG functionalization, respectively.

The higher surface roughness for APTMS and PEG can be related with the wettability measured by contact angle. Wenzel stated that even small changes in surface roughness can enhance the wettability characteristics caused by the chemistry of the surface [55]. In the case of APTMS the higher surface roughness contributed to the enhanced 

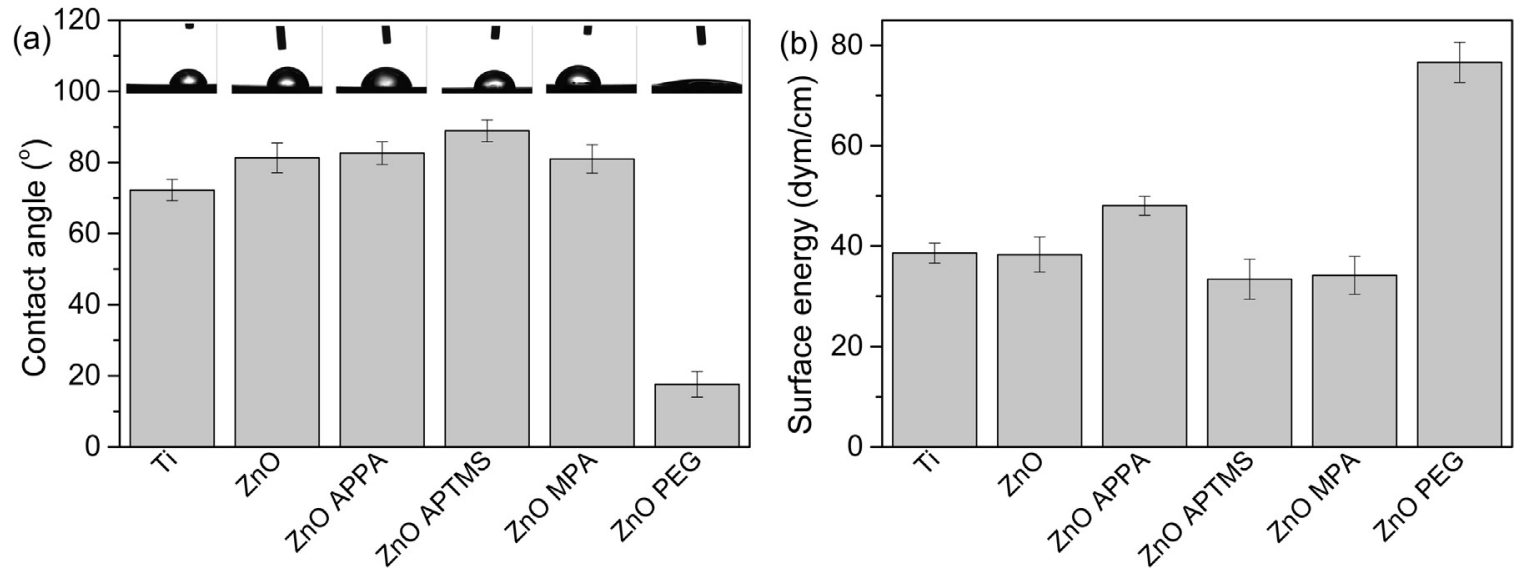

Fig. 6. Water contact angles (a) and surface energy (b) measured on surfaces of titanium, pristine and functionalized ZnO thin films.

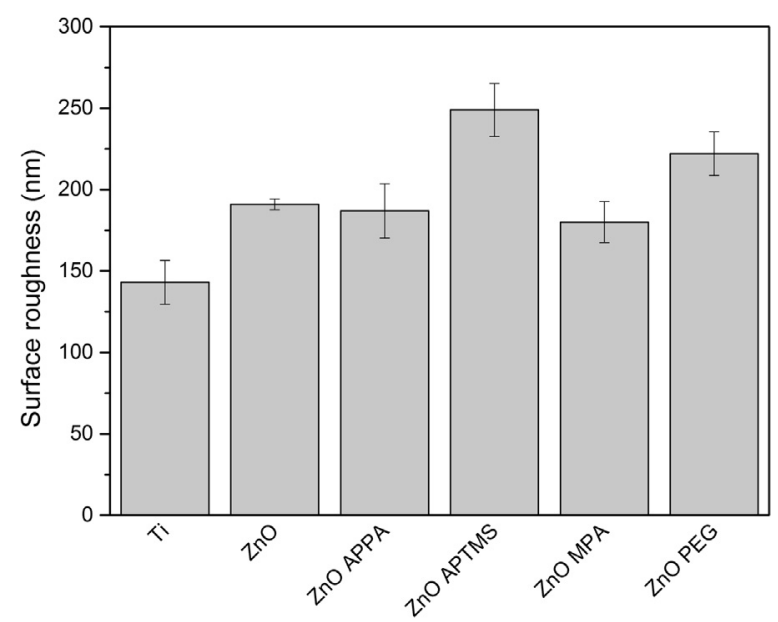

Fig. 7. Arithmetic mean surface roughness (Ra) for the pristine Ti substrate, $\mathrm{ZnO}$ thin film, and the functionalized oxide thin films.

contact angle measured. On the other hand, PEG showed a more hydrophilic characteristic that can be attributed to an increase in Ra value. Besides the difference in surface roughness for the functionalized $\mathrm{ZnO}$ thin films, the Ra value is in the range of the available dental implants [30-32].

\subsection{Electrochemical measurements}

Understanding the physicochemical changes that $\mathrm{ZnO}$ surface functionalization may promote on titanium implants is important. Moreover, to evaluate the electrochemical behavior of these functional surfaces in biological environment is imperative for a good implant performance. Fig. 7 shows the open circuit potentials $\left(E_{O C P}\right)$ as a function of time for pristine and functionalized $\mathrm{ZnO}$ thin films in PBS electrolyte. The $\mathrm{E}_{\mathrm{OCP}}$ stability with time is an indication that no significant change occurs on the surface under these exposure conditions. In general, the higher the $\mathrm{E}_{\mathrm{OCP}}$ the lower is the tendency of corrosion [5]. It is clearly seen in Fig. 8 that the $\mathrm{ZnO}$ thin films significantly increase the $\mathrm{E}_{\mathrm{OCP}}$ value, suggesting a higher resistance to corrosion when compared to pristine Ti. In particular, ZnO functionalized with APPA and APTMS molecules exhibited higher $\mathrm{E}_{\mathrm{OCP}}$ compared to ZnO. Organic molecules as APPA and APTMS, are deposited with higher density due to an increase in Van der Waals force or hydrophobic interactions [56]. In this way, APPA and APTMS molecules can improve the corrosion resistance of the material by isolating the Ti substrate from the environment and preventing the approach of corrosive ions. In the case of MPA and PEG molecules, a slightly decrease in $\mathrm{E}_{\mathrm{OCP}}$ is observed in

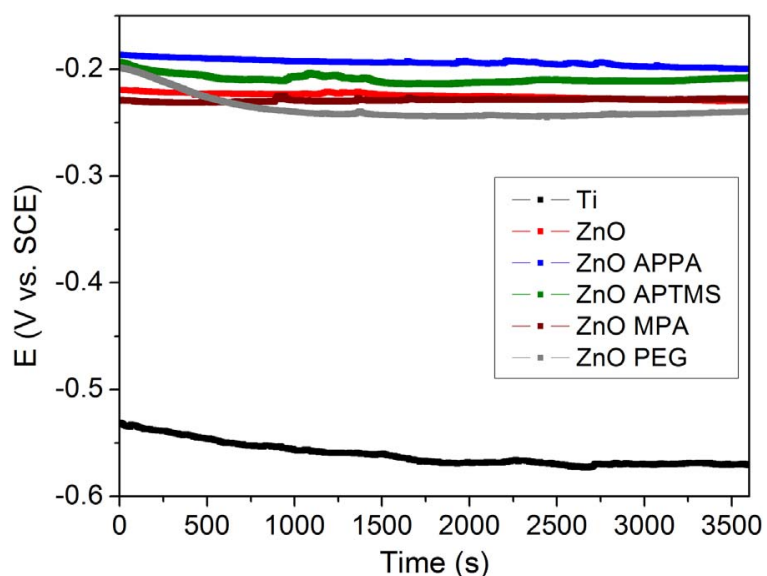

Fig. 8. Evolution of $\mathrm{E}_{\mathrm{OCP}}$ for the pristine $\mathrm{Ti}, \mathrm{ZnO}$ and $\mathrm{ZnO}$ functionalized with the organic bifunctional molecules.

comparison with $\mathrm{ZnO}$. It might be due to the presence of defects or water and oxygen molecules which can lead to the degradation of the organic material [57].

The Bode plot represented by impedance $(\mathrm{Z})$ modulus as function of frequency in Fig. 9a shows that the Ti sample have $\mathrm{Z}<10^{4} \Omega \mathrm{cm}^{2}$ at low frequencies, whereas for other samples, except for ZnO PEG, this value is $>10^{5} \Omega \mathrm{cm}^{2}$ at same frequencies, indicating that pristine and $\mathrm{ZnO}$ functionalized thin films have better corrosion resistance [58]. However, at higher frequencies for non-functionalized $\mathrm{ZnO}$ thin film the response indicates possible oxide layer breakdown [59], which can be related to surface defects such as uncoated regions, cracks or a high density of pinholes. On the other hand, the functionalized $\mathrm{ZnO}$ samples exhibit a behavior associated to an intact layer [60]. Moreover, the presence of pristine and $\mathrm{ZnO}$ functionalized thin films on Ti surface may prevent the penetration of ions from PBS electrolyte and slows down the charge transfer at the functionalized $\mathrm{ZnO}$ /substrate interface thereby reducing the reaction kinetics for $\mathrm{Ti}_{(\text {aq) }}^{4+}$ or $\mathrm{Ti}_{\text {(aq) }}^{3+}$ formation. The phase angle plots in Fig. 9b can be classified in high and low frequency regions, providing the relaxation processes at surface layer/electrolyte and substrate/surface layer interfaces respectively [58]. In the medium frequency range, the phase angle and frequency shows a linear response for pristine Ti with phase angles approaching to $60^{\circ}$, which corresponds to the capacitive behavior of the electrode/electrolyte interface [7]. The decrease in phase angle and shift in peak position around $10^{1} \mathrm{~Hz}$ confirms the breakdown of the $\mathrm{ZnO}$ layer, however the functionalized ZnO samples shows a breakdown point at higher frequencies $\left(>10^{2} \mathrm{~Hz}\right.$ ) when compared to pristine $\mathrm{ZnO}$ thin film indicating increased resistance to oxide rupture. The fitting for phase angle plots are 

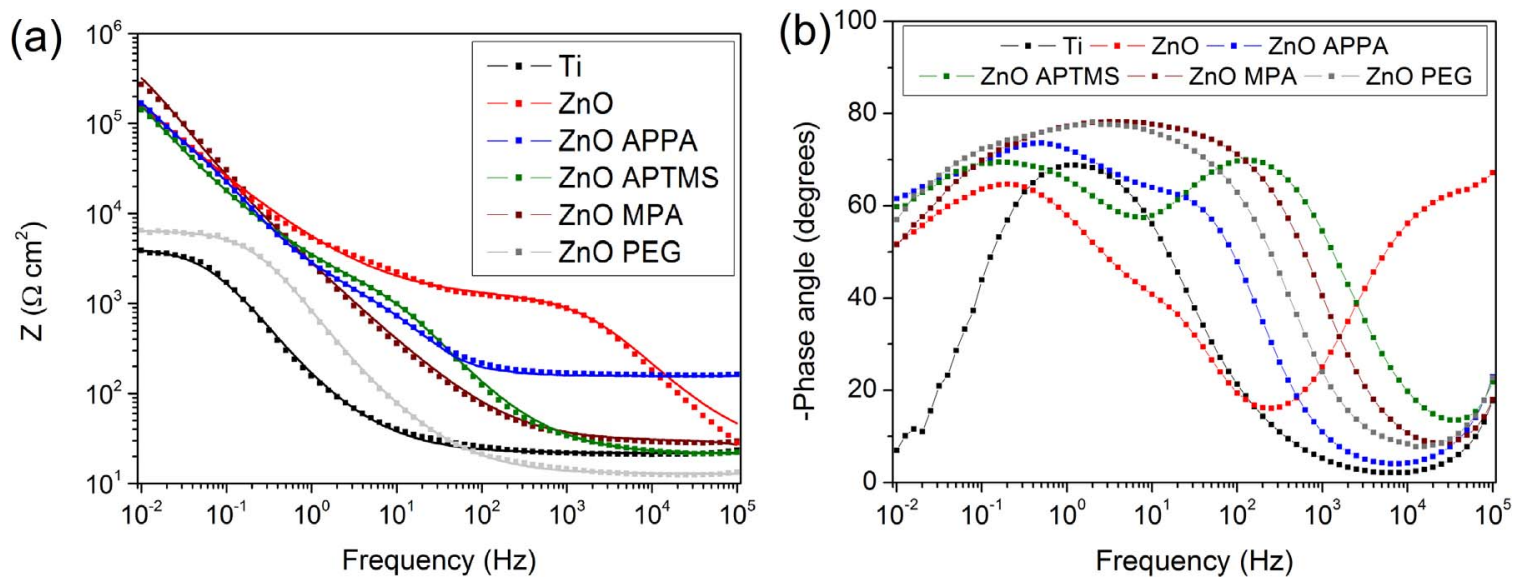

Fig. 9. Bode plots (a) and impedance phase angle plot (b) for $\mathrm{Ti}, \mathrm{ZnO}$ and functionalized $\mathrm{ZnO}$ samples.

(a)

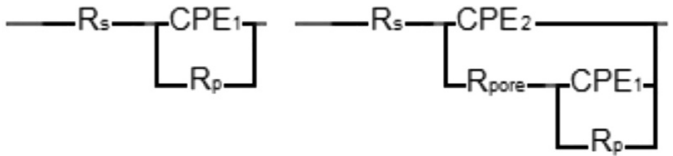

Fig. 10. Equivalent circuit with one time constant for pristine $\mathrm{Ti}, \mathrm{ZnO}$ functionalized with MPA and PEG (a). An equivalent circuit with two time constant is presented for $\mathrm{ZnO}$ thin film and ZnO functionalized with APPA and APTMS (b).

\section{shown in Fig. S2-S7.}

Based on the EIS behavior, equivalent circuits are proposed to the experimental data, as shown in Fig. 10. A constant phase element (CPE) was used instead of a pure capacitor due to the non-ideal behavior associated to the experimental conditions. The impedance of $\mathrm{CPE}\left(\mathrm{Z}_{\mathrm{CPE}}\right)$ is defined as $\mathrm{Z}_{\mathrm{CPE}}=\left[\mathrm{Z}_{\mathrm{o}}(j \omega)^{\mathrm{n}}\right]^{-1}$, where $\mathrm{Z}_{\mathrm{o}}$ is the CPE constant $\left(\Omega^{-1} \mathrm{~cm}^{-2} s^{\mathrm{n}}\right), \omega$ is the angular frequency $\left(\operatorname{rad~s}^{-1}\right), j$ is the imaginary number and $n$ is the CPE exponent [61]. When $\mathrm{n}=1$ the CPE behaves as an ideal capacitor, for $0.5<\mathrm{n}<1$ the CPE describes a distribution of dielectric relaxation times in frequency space and when $n=0.5$ the CPE represents a Warburg impedance with diffusion character [7]. The electrolyte solution resistance is represented by $R_{s}$, which is small and similar in all the EIS tests. Pristine Ti equivalent circuit, $\mathrm{ZnO}$ functionalized with MPA and PEG (Fig. 10a) are represented by a Randle's model with CPE [62]. The arrangement of two cascaded CPE for modified Ti with $\mathrm{ZnO}$ and $\mathrm{ZnO}$ functionalized with APPA and APTMS (Fig. 10b) are represented by an inner layer $\left(\mathrm{R}_{\mathrm{p}}\right.$ and $\left.\mathrm{CPE}_{1}\right)$ and an outer porous layer $\left(\mathrm{R}_{\mathrm{pore}}\right.$ and $\left.\mathrm{CPE}_{2}\right)$. The notations $\mathrm{R}_{\mathrm{p}}$ and $\mathrm{R}_{\mathrm{pore}}$ corresponds to the resistances of the inner barrier and outer porous layers respectively.

Table 1 shows the electrochemical parameters obtained from the fitting procedures. The parameter $R_{p}$ is often used to evaluate the corrosion resistance of the working electrode since it includes the contributions of the charge-transfer resistances, the oxide thin film resistance and the migration of point defects mediated metal dissolution [63]. Comparison of the resistance values from the fitting results shows that the resistance of the outer porous layer $\left(R_{\text {pore }}\right)$ is lower than the resistance of the inner barrier layer $\left(R_{p}\right)$ which indicates a higher corrosion resistance provided by $R_{p}$. In contrast with pristine $T i, R_{p}$ values for $\mathrm{ZnO}$ and $\mathrm{ZnO}$ functionalized thin films are approximately three orders of magnitude higher, with exception for ZnO PEG, demonstrating that the surface functionalization can inhibit charge transfer at substrate/electrolyte interface and reduces metallic ions release consequently enhancing the corrosion resistance [7]. The goodness of fit $\left(\chi^{2}\right)$ values was of the order of $10^{-3}$ corroborating the good quality of the fitting procedure.

The corrosion was analyzed by the corrosion current density ( $\left.\mathrm{I}_{\text {corr }}\right)$ and corrosion potential $\left(\mathrm{E}_{\mathrm{corr}}\right)$, which were estimated using the Tafel extrapolation from potentiodynamic polarization data. The corresponding electrochemical parameters are summarized in Fig. 11. Compared to pristine $\mathrm{Ti}$, the corrosion potentials of $\mathrm{ZnO}$ functionalized samples shift positively indicating a suppression of Ti dissolution caused by the protective nature of the $\mathrm{ZnO}$ thin film and organic molecules. The $\mathrm{E}_{\text {corr }}$ potential decreased from $-0.63 \mathrm{~V}$ for pristine $\mathrm{Ti}$, to $-0.51 \mathrm{~V},-0.47 \mathrm{~V},-0.46 \mathrm{~V},-0.44 \mathrm{~V},-0.40 \mathrm{~V}$, for ZnO PEG, ZnO APTMS, ZnO APPA, ZnO, and ZnO MPA sample respectively.

In addition, lower values are observed for corrosion current density $\left(\mathrm{I}_{\text {corr }}\right)$ in functionalized samples, supporting the idea of higher corrosion

Table 1

Electrochemical parameters extracted from Nyquist plot fitting for the analyzed samples.

\begin{tabular}{|c|c|c|c|c|c|c|c|c|}
\hline \multirow[t]{2}{*}{ Sample } & \multicolumn{8}{|c|}{ Parameters } \\
\hline & $\begin{array}{l}\mathrm{R}_{\mathrm{s}} \\
\left(\Omega \mathrm{cm}^{2}\right)\end{array}$ & $\begin{array}{l}\mathrm{R}_{\mathrm{P}} \\
\left(\Omega \mathrm{cm}^{2}\right)\end{array}$ & $\begin{array}{l}\mathrm{CPE}_{1} \\
\left(\Omega^{-1} \mathrm{~S}^{\mathrm{n}} \mathrm{cm}^{-2}\right)\end{array}$ & $\mathrm{n}_{1}$ & $\begin{array}{l}\mathrm{R}_{\text {pore }} \\
\left(\Omega \mathrm{cm}^{2}\right)\end{array}$ & $\begin{array}{l}\mathrm{CPE}_{2} \\
\left(\Omega^{-1} \mathrm{~S}^{\mathrm{n}} \mathrm{cm}^{-2}\right)\end{array}$ & $\mathrm{n}_{2}$ & $\chi^{2}$ \\
\hline $\mathrm{Ti}$ & $\begin{array}{l}21.9 \\
( \pm 2.64)\end{array}$ & $\begin{array}{l}4.14 \times 10^{3} \\
( \pm 54.0)\end{array}$ & $\begin{array}{l}4.64 \times 10^{-4} \\
( \pm 0.32)\end{array}$ & $\begin{array}{l}0.848 \\
( \pm 0.05)\end{array}$ & - & - & - & $\begin{array}{l}5.79 \times 10^{-3} \\
( \pm 0.06)\end{array}$ \\
\hline $\mathrm{ZnO}$ & $\begin{array}{l}20.5 \\
( \pm 8.33)\end{array}$ & $\begin{array}{l}1.01 \times 10^{6} \\
( \pm 124)\end{array}$ & $\begin{array}{l}2.48 \times 10^{-5} \\
( \pm 0.49)\end{array}$ & $\begin{array}{l}0.724 \\
( \pm 0.24)\end{array}$ & $\begin{array}{l}1.26 \times 10^{3} \\
( \pm 5.06)\end{array}$ & $\begin{array}{l}5.43 \times 10^{-7} \\
( \pm 0.54)\end{array}$ & $\begin{array}{l}0.767 \\
( \pm 0.20)\end{array}$ & $\begin{array}{l}7.90 \times 10^{-3} \\
( \pm 0.15)\end{array}$ \\
\hline ZnO APPA & $\begin{array}{l}35.0 \\
( \pm 5.12)\end{array}$ & $\begin{array}{l}4.58 \times 10^{4} \\
( \pm 91.4)\end{array}$ & $\begin{array}{l}3.86 \times 10^{-5} \\
( \pm 0.68)\end{array}$ & $\begin{array}{l}0.863 \\
( \pm 0.11)\end{array}$ & $\begin{array}{l}4.68 \times 10^{1} \\
( \pm 2.84)\end{array}$ & $\begin{array}{l}2.36 \times 10^{-5} \\
( \pm 0.91)\end{array}$ & $\begin{array}{l}0.863 \\
( \pm 0.13)\end{array}$ & $\begin{array}{l}5.95 \times 10^{-3} \\
( \pm 0.32)\end{array}$ \\
\hline ZnO APTMS & $\begin{array}{l}21.4 \\
( \pm 3.69)\end{array}$ & $\begin{array}{l}1.01 \times 10^{6} \\
( \pm 159)\end{array}$ & $\begin{array}{l}1.70 \times 10^{-5} \\
( \pm 0.76)\end{array}$ & $\begin{array}{l}0.795 \\
( \pm 0.20)\end{array}$ & $\begin{array}{l}4.19 \times 10^{3} \\
( \pm 1.61)\end{array}$ & $\begin{array}{l}1.21 \times 10^{-5} \\
( \pm 0.62)\end{array}$ & $\begin{array}{l}0.840 \\
( \pm 0.11)\end{array}$ & $\begin{array}{l}5.35 \times 10^{-3} \\
( \pm 0.49)\end{array}$ \\
\hline ZnO MPA & $\begin{array}{l}28.3 \\
( \pm 3.27)\end{array}$ & $\begin{array}{l}8.15 \times 10^{5} \\
( \pm 143)\end{array}$ & $\begin{array}{l}1.68 \times 10^{-5} \\
( \pm 0.21)\end{array}$ & $\begin{array}{l}0.861 \\
( \pm 0.04)\end{array}$ & - & - & - & $\begin{array}{l}4.85 \times 10^{-3} \\
( \pm 0.76)\end{array}$ \\
\hline ZnO PEG & $\begin{array}{l}12.8 \\
( \pm 2.32)\end{array}$ & $\begin{array}{l}6.48 \times 10^{3} \\
( \pm 31.2)\end{array}$ & $\begin{array}{l}1.04 \times 10^{-4} \\
( \pm 0.59)\end{array}$ & $\begin{array}{l}0.864 \\
( \pm 0.12)\end{array}$ & - & - & - & $\begin{array}{l}3.19 \times 10^{-3} \\
( \pm 0.62)\end{array}$ \\
\hline
\end{tabular}



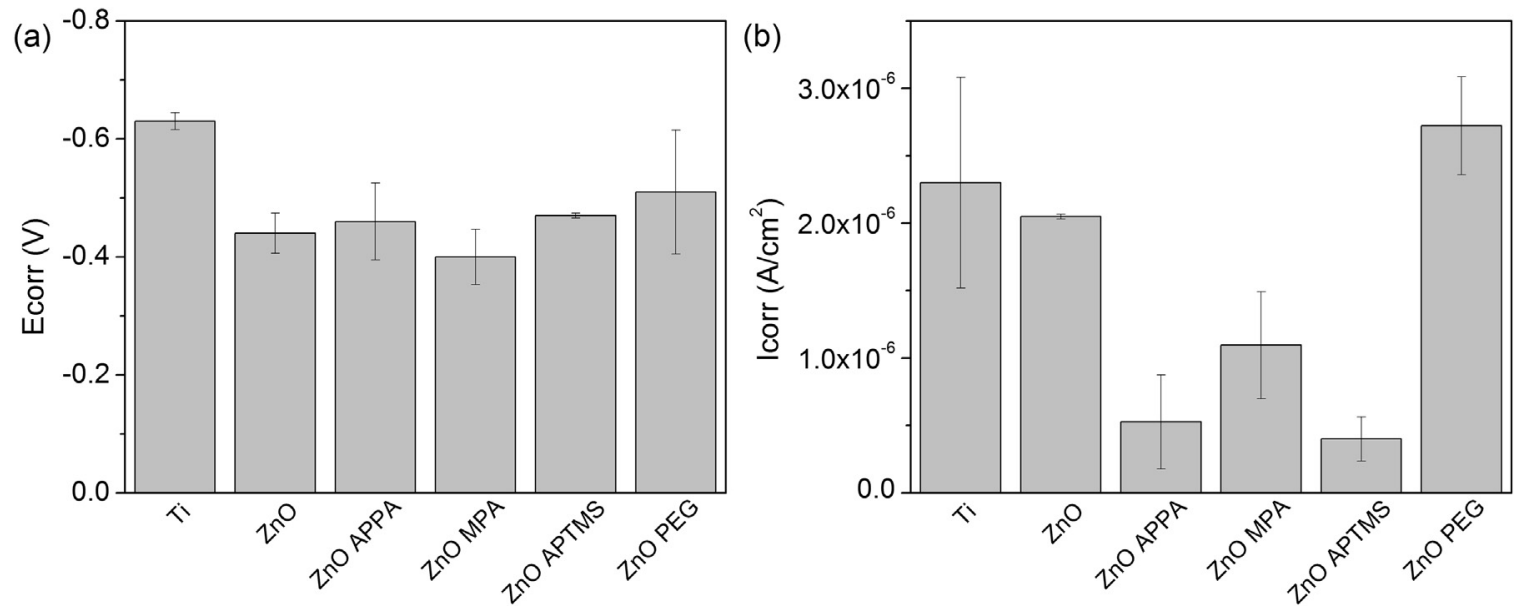

Fig. 11. Corrosion potential, $E_{\text {corr }}(a)$ and corrosion current density, $I_{\text {corr }}$ (b) are shown for all analyzed samples.

stability due to the $\mathrm{ZnO}$ thin film. The functionalization decreased the $\mathrm{I}_{\text {corr }}$ values from $2.0 \times 10^{-6} \mathrm{~A} / \mathrm{cm}^{2}$ for $\mathrm{ZnO}$, to $5.3 \times 10^{-7} \mathrm{~A} / \mathrm{cm}^{2}, 1.1$ $\times 10^{-6} \mathrm{~A} / \mathrm{cm}^{2}$, and $3.9 \times 10^{-7} \mathrm{~A} / \mathrm{cm}^{2}$, for APPA, MPA, and APTMS bifunctional molecules respectively. This phenomenon is observed since the organic coatings from APPA, MPA, and APTMS provides a better barrier protection preventing corrosion. However, the $\mathrm{I}_{\text {corr }}$ value for ZnO PEG sample $\left(2.7 \times 10^{-6} \mathrm{~A} / \mathrm{cm}^{2}\right)$ is higher than that for pristine $\mathrm{Ti}$ $\left(2.3 \times 10^{-6} \mathrm{~A} / \mathrm{cm}^{2}\right)$. This is related to the higher wettability of $\mathrm{ZnO}$ functionalized with PEG. At lower contact angle values the material can absorb more water molecules increasing the corrosion and degradation rates [61].

Therefore, the electrochemical results indicated that the Ti cp4 modified with $\mathrm{ZnO}$ and organic molecules shifted the $\mathrm{E}_{\mathrm{OCP}}$ to noble potentials, decreased the corrosion current density and enhanced the resistance of the material, significantly increasing the corrosion resistance of pristine Ti.

\section{Conclusions}

Ti cp4 substrates were modified by sol-gel synthesized $\mathrm{ZnO}$ thin films. As-deposited $\mathrm{ZnO}$ thin films were functionalized with APPA, APTMS, MPA, and PEG bifunctional molecules. The adhesion mechanism for the organic molecules were proposed based on XPS data, indicating that the attachment on $\mathrm{ZnO}$ surface occurs through carboxylic acid, silane, thiol, and hydroxyl groups for APPA, APTMS, MPA, and PEG, respectively. The functionalization also led to different wettability and surface energy behavior, depending on the free terminal group present on $\mathrm{ZnO}$ surface. Electrochemical analysis showed that $\mathrm{ZnO}$ functionalized with the organic bifunctional molecules presented higher $\mathrm{E}_{\mathrm{OCP}}$ values associated with increased corrosion resistance. Considering the results obtained, $\mathrm{ZnO}$ functionalized with APPA showed enhanced properties indicating promising applications in biomedical devices. Therefore, the ZnO APPA showed high surface energy, noble open circuit potentials $(-0.2 \mathrm{~V})$, and significant decrease in the corrosion current density $\left(5.3 \times 10^{-7} \mathrm{~A} / \mathrm{cm}^{2}\right)$, indicating promising interaction with biomolecules from the biological environment and an increase in corrosion resistance.

Nevertheless, as pointed by this work, more efforts are necessary to study the bifunctional molecules adhesion and its applicability in implants. Future work will focus on the bactericidal effect, cell viability, and tribocorrosion aspects from the samples.

\section{Acknowledgment}

This work was financially supported by FAPESP (2013/07296-2, 2013/09963-6, 2014/01713-3, and 2014/20471-0) and CAPES.

\section{Appendix A. Supplementary material}

Supplementary data associated with this article can be found in the online version at http://dx.doi.org/10.1016/j.ceramint.2017.11.195.

\section{References}

[1] R. Wang, X. He, Y. Gao, X. Zhang, X. Yao, B. Tang, Antimicrobial property, cytocompatibility and corrosion resistance of $\mathrm{Zn}$-doped $\mathrm{ZrO} 2 / \mathrm{TiO} 2$ coatings on Ti6Al4V implants, Mater. Sci. Eng. C 75 (2017) 7-15.

[2] H. Hu, W. Zhang, Y. Qiao, X. Jiang, X. Liu, C. Ding, Antibacterial activity and increased bone marrow stem cell functions of $\mathrm{Zn}$-incorporated TiO2 coatings on titanium, Acta Biomater. 8 (2012) 904-915.

[3] H. Zhang, B. Chen, H. Jiang, C. Wang, H. Wang, X. Wang, A strategy for ZnO nanorod mediated multi-mode cancer treatment, Biomaterials 32 (2011) 1906-1914.

[4] H. Hong, J. Shi, Y. Yang, Y. Zhang, J.W. Engle, R.J. Nickles, X. Wang, W. Cai, Cancer-targeted optical imaging with fluorescent zinc oxide nanowires, Nano Lett. 11 (2011) 3744-3750.

[5] I. Cvijović-Alagić, Z. Cvijović, S. Mitrović, V. Panić, M. Rakin, Wear and corrosion behaviour of Ti-13Nb-13Zr and Ti-6Al-4V alloys in simulated physiological solution, Corros. Sci. 53 (2011) 796-808.

[6] S.J. Lugowski, D.C. Smith, A.D. McHugh, J.C. Van Loon, Release of metal ions from dental implant materials in vivo: determination of $\mathrm{Al}, \mathrm{Co}, \mathrm{Cr}, \mathrm{Mo}, \mathrm{Ni}, \mathrm{V}$, and $\mathrm{Ti}$ in organ tissue, J. Biomed. Mater. Res. 25 (1991) 1443-1458.

[7] X. Zhang, H. Wang, J. Li, X. He, R. Hang, X. Huang, L. Tian, B. Tang, Corrosion behavior of $\mathrm{Zn}$-incorporated antibacterial $\mathrm{TiO} 2$ porous coating on titanium, Ceram. Int. 42 (2016) 17095-17100.

[8] J.P. Landsberg, B. McDonald, F. Watt, Absence of aluminium in neuritic plaque cores in Alzheimer's disease, Nature 360 (1992) 65-68.

[9] T. Hanawa, Metal ion release from metal implants, Mater. Sci. Eng. C 24 (2004) $745-752$.

[10] S. Rao, T. Ushida, T. Tateishi, Y. Okazaki, S. Asao, Effect of Ti, Al, and V ions on the relative growth rate of fibroblasts (L929) and osteoblasts (MC3T3-E1) cells, Biomed. Mater. Eng. 6 (1996) 79-86.

[11] H.R. Bakhsheshi-Rad, E. Hamzah, M. Daroonparvar, R. Ebrahimi-Kahrizsangi, M. Medraj, In-vitro corrosion inhibition mechanism of fluorine-doped hydroxyapatite and brushite coated $\mathrm{Mg}-\mathrm{Ca}$ alloys for biomedical applications, Ceram. Int. 40 (2014) 7971-7982.

[12] P. Shi, B. Niu, S.E., Y. Chen, Q. Li, Preparation and characterization of PLA coating and PLA/MAO composite coatings on AZ31 magnesium alloy for improvement of corrosion resistance, Surf. Coat. Technol. 262 (2015) 26-32.

[13] K. Huang, S. Cai, G. Xu, M. Ren, X. Wang, R. Zhang, S. Niu, H. Zhao, Sol-gel derived mesoporous 58S bioactive glass coatings on AZ31 magnesium alloy and in vitro degradation behavior, Surf. Coat. Technol. 240 (2014) 137-144.

[14] G. Wu, A. Shanaghi, Y. Zhao, X. Zhang, R. Xu, Z. Wu, G. Li, P.K. Chu, The effect of interlayer on corrosion resistance of ceramic coating $/ \mathrm{Mg}$ alloy substrate in simulated physiological environment, Surf. Coat. Technol. 206 (2012) 4892-4898.

[15] S.Z. Khalajabadi, M.R. Abdul Kadir, S. Izman, M. Kasiri-Asgarani, Microstructural characterization, biocorrosion evaluation and mechanical properties of nanostructured $\mathrm{ZnO}$ and $\mathrm{Si} / \mathrm{ZnO}$ coated $\mathrm{Mg} / \mathrm{HA} / \mathrm{TiO} 2 / \mathrm{MgO}$ nanocomposites, Surf. Coat. Technol. 277 (2015).

[16] S. Shen, Y. Zuo, The improved performance of Mg-rich epoxy primer on AZ91D magnesium alloy by addition of ZnO, Corros. Sci. 87 (2014) 167-178.

[17] H. Chen, C.P. Chen, C.-T.R. Yu, Y.T. Chen, C.-C. Teng, K.-Y. Lo, C.H. Lin, B. Y. Huang, Distinct spatial profiles and antibacterial effects of 20-nm Ag nanoparticles dripped on $\mathrm{ZnO}$ nanorods grown on a polished Ti substrate, Appl. Surf. Sci. 311 (2014) 422-425.

[18] S. Ferraris, S. Spriano, Antibacterial titanium surfaces for medical implants, Mater. 
Sci. Eng. C 61 (2016) 965-978.

[19] A.M. Rosa, E.P. da Silva, M. Chaves, L.D. Trino, P.N. Lisboa-Filho, T.F. da Silva, S.F. Durrant, J.R.R. Bortoleto, Structural transition of $\mathrm{ZnO}$ thin films produced by RF magnetron sputtering at low temperatures, J. Mater. Sci. Mater. Electron. 24 (2013) 3143-3148.

[20] C.G. Allen, D.J. Baker, J.M. Albin, H.E. Oertli, D.T. Gillaspie, D.C. Olson, T.E. Furtak, R.T. Collins, Surface modification of $\mathrm{ZnO}$ using triethoxysilane-based molecules, Langmuir 24 (2008) 13393-13398.

[21] B. Zhang, T. Kong, W. Xu, R. Su, Y. Gao, G. Cheng, Surface functionalization of zinc oxide by carboxyalkylphosphonic acid self-assembled monolayers, Langmuir 26 (2010) 4514-4522.

[22] W.-C. Chen, Y. Lo, H.-S. Chen, Effects of Ti surface treatments with silane and arginylglycylaspartic acid peptide on bone cell progenitors, Odontology 103 (2015) 322-332.

[23] J. Shen, Y. Qi, B. Jin, X. Wang, Y. Hu, Q. Jiang, Control of hydroxyapatite coating by self-assembled monolayers on titanium and improvement of osteoblast adhesion, J. Biomed. Mater. Res. B Appl. Biomater. 105 (2017) 124-135.

[24] J. Buxadera-Palomero, C. Calvo, S. Torrent-Camarero, F.J. Gil, C. Mas-Moruno, C. Canal, D. Rodríguez, Biofunctional polyethylene glycol coatings on titanium: an in vitro-based comparison of functionalization methods, Colloids Surf. B Biointerfaces 152 (2017) 367-375.

[25] Z. Wei, Y.F. Liu, S. Chi, Z. Xu, J, A facile approach to surface modification on versatile substrates for biological applications, J. Mater. Chem. (RSC Publishing) 22 (2012) 17159-17166.

[26] R. Chen, M.D.P. Willcox, K.K.K. Ho, D. Smyth, N. Kumar, Antimicrobial peptide melimine coating for titanium and its in vivo antibacterial activity in rodent subcutaneous infection models, Biomaterials 85 (2016) 142-151.

[27] M. Roy, A. Pompella, J. Kubacki, J. Szade, R.A. Roy, W. Hedzelek, Photofunctionalization of titanium: an alternative explanation of its chemicalphysical mechanism, PLoS One 11 (2016) e0157481.

[28] P. Silva-Bermudez, S.E. Rodil, An overview of protein adsorption on metal oxide coatings for biomedical implants, Surf. Coat. Technol. 233 (2013) 147-158.

[29] B.S. Barros, R. Barbosa, N.R. dos Santos, T.S. Barros, M.A. Souza, Synthesis and Xray diffraction characterization of nanocrystalline $\mathrm{ZnO}$ obtained by Pechini method, Inorg. Mater. 12 (2006) 1348-1351.

[30] M. Sezin, L. Croharé, J.C. Ibañez, Microscopic study of surface microtopographic characteristics of dental implants, Open Dent. J. 10 (2016) 139-147.

[31] C.F. Ramel, A. Lüssi, M. Özcan, R.E. Jung, C.H.F. Hämmerle, D.S. Thoma, Surface roughness of dental implants and treatment time using six different implantoplasty procedures, Clin. Oral. Implants Res. 27 (2016) 776-781.

[32] A.P.R.K. Alla, K. Ginjupalli, N. Upadhya, S. Mohammed, R. Chandra sekar, R. Krishna Ravi, Surface roughness of implants: a review, Trends Biomater. Artif. Organs 25 (2011) 112-118.

[33] C. Amutha, S. Thanikaikarasan, V. Ramadas, S.A. Bahadur, B. Natarajan, R. Kalyani, Synthesis, characterization and antibacterial efficiency of $\mathrm{ZnO}$ nanoparticles using rice as soft bio-template, Opt. - Int. J. Light Electron Opt. 127 (2016) 4281-4286.

[34] S.P. Pujari, L. Scheres, A.T.M. Marcelis, H. Zuilhof, Covalent surface modification of oxide surfaces, Angew. Chem. Int. Ed. 53 (2014) 6322-6356.

[35] T. Hanawa, Biofunctionalization of titanium for dental implant, Jpn. Dent. Sci. Rev. 46 (2010) 93-101.

[36] J.F. Moulder, Handbook of X-ray Photoelectron Spectroscopy: A Reference Book of Standard Spectra for Identification and Interpretation of XPS Data, Physical Electronics Division, Perkin-Elmer Corporation, 1992.

[37] N. Plylahan, S. Maria, T.N. Phan, M. Letiche, H. Martinez, C. Courrèges, P. Knauth, T. Djenizian, Enhanced electrochemical performance of Lithium-ion batteries by conformal coating of polymer electrolyte, Nanoscale Res. Lett. 9 (2014) 544.

[38] Y.L. Khung, S.H. Ngalim, A. Scaccabarozi, D. Narducci, Thermal and UV hydrosilylation of alcohol-based Bifunctional Alkynes on Si (111) surfaces: how surface radicals influence surface bond formation, Sci. Rep. 5 (2015) 11299.

[39] E. Ataman, C. Isvoranu, J. Knudsen, K. Schulte, J.N. Andersen, J. Schnadt, Adsorption of L-cysteine on rutile TiO2(110), Surf. Sci. 605 (2011) 179-186.

[40] G.J. Fleming, K. Adib, J.A. Rodriguez, M.A. Barteau, J.M. White, H. Idriss, The adsorption and reactions of the amino acid proline on rutile TiO2(110) surfaces, Surf. Sci. 602 (2008) 2029-2038.

[41] Y.-Y. Song, H. Hildebrand, P. Schmuki, Optimized monolayer grafting of 3-aminopropyltriethoxysilane onto amorphous, anatase and rutile TiO2, Surf. Sci. 604 (2010) 346-353.

[42] M.A. Chamjangali, S. Boroumand, Synthesis of flower-like Ag-ZnO nanostructure and its application in the photodegradation of methyl orange, J. Braz. Chem. Soc. 24 (2013) 1329-1338.

[43] J.N. Wilson, R.M. Dowler, H. Idriss, Adsorption and reaction of glycine on the rutile TiO2(011) single crystal surface, Surf. Sci. 605 (2011) 206-213.

[44] K.L. Mittal, Silanes and Other Coupling Agents, CRC Press, 2009.

[45] J.A. Wingrave, Oxide Surfaces, CRC Press, 2001.

[46] M.E. Marques, A.A.P. Mansur, H.S. Mansur, Chemical functionalization of surfaces for building three-dimensional engineered biosensors, Appl. Surf. Sci. 275 (2013) 347-360.

[47] P.Y. Dave, K.H. Patel, K.V. Chauhan, A.K. Chawla, S.K. Rawal, Examination of zinc oxide films prepared by magnetron sputtering, Procedia Technol. 23 (2016) 328-335

[48] K.M. Hotchkiss, G.B. Reddy, S.L. Hyzy, Z. Schwartz, B.D. Boyan, R. OlivaresNavarrete, Titanium surface characteristics, including topography and wettability, alter macrophage activation, Acta Biomater. 31 (2016) 425-434.

[49] J.M. Harris, Poly(Ethylene Glycol) Chemistry: Biotechnical and Biomedical Applications, Springer Science \& Business Media, 1992.

[50] A. Papra, N. Gadegaard, N.B. Larsen, Characterization of ultrathin poly(ethylene glycol) monolayers on silicon substrates, Langmuir 17 (2001) 1457-1460.

[51] R.K. Sharma, M. Agarwal, K. Balani, Effect of ZnO morphology on affecting bactericidal property of ultra high molecular weight polyethylene biocomposite, Mater Sci. Eng. C 62 (2016) 843-851.

[52] C. Eriksson, H. Nygren, K. Ohlson, Implantation of hydrophilic and hydrophobic titanium discs in rat tibia: cellular reactions on the surfaces during the first 3 weeks in bone, Biomaterials 25 (2004) 4759-4766.

[53] A.V. Rudakova, U.G. Oparicheva, A.E. Grishina, A.A. Murashkina, A.V. Emeline, D.W. Bahnemann, Photoinduced hydrophilic conversion of hydrated $\mathrm{ZnO}$ surfaces, J. Colloid Interface Sci. 466 (2016) 452-460.

[54] K.H. Patel, S.K. Rawal, Exploration of wettability and optical aspects of ZnO nano thin films synthesized by radio frequency magnetron sputtering, Nanomater. Nanotechnol. 6 (2016) 22.

[55] R.N. Wenzel, Resistance of solid surfaces to wetting by water, Ind. Eng. Chem. 28 (1936) 988-994.

[56] M. Advincula, X. Fan, J. Lemons, R. Advincula, Surface modification of surface sol-gel derived titanium oxide films by self-assembled monolayers (SAMs) and nonspecific protein adsorption studies, Colloids Surf. B Biointerfaces 42 (2005) 29-43.

[57] V.I. Madogni, B. Kounouhéwa, A. Akpo, M. Agbomahéna, S.A. Hounkpatin, C.N. Awanou, Comparison of degradation mechanisms in organic photovoltaic devices upon exposure to a temperate and a subequatorial climate, Chem. Phys. Lett. 640 (2015) 201-214.

[58] A. Srinivasan, K.S. Shin, N. Rajendran, Applications of dynamic electrochemical impedance spectroscopy (DEIS) to evaluate protective coatings formed on AZ31 magnesium alloy, RSC Adv. 5 (2015) 29589-29593.

[59] R.G. Kelly, J.R. Scully, D. Shoesmith, R.G. Buchheit, Electrochemical Techniques in Corrosion Science and Engineering, CRC Press, 2002.

[60] H.P. Hack, J.R. Scully, Defect area determination of organic coated steels in seawater using the breakpoint frequency method, J. Electrochem. Soc. 138 (1991) 33-40.

[61] L. Liu, J. Xu, P. Munroe, J. Xu, Z.H. Xie, Electrochemical behavior of (Ti1 - xNbx) 5 Si3 nanocrystalline films in simulated physiological media, Acta Biomater. 10 (2014) 1005-1013.

[62] P. Ducheyne, K. Healy, D.E. Hutmacher, D.W. Grainger, C.J. Kirkpatrick, Comprehensive Biomaterials, Elsevier, 2011.

[63] H. Krawiec, V. Vignal, E. Schwarzenboeck, J. Banas, Role of plastic deformation and microstructure in the micro-electrochemical behaviour of Ti-6Al-4V in sodium chloride solution, Electrochim. Acta 104 (2013) 400-406. 